\title{
EFEKTIFITAS PEMANFAATAN MEDIA PEMBELAJARAN BERBASIS ETNOMATEMATIKA TERHADAP PRESTASI AKADEMIK MAHASISWA PROGRAM STUDI PENDIDIKAN MATEMATIKA
}

\author{
Sri Rahmah Dewi Saragih ${ }^{1}$, Rina Hayati Maulidah ${ }^{2}$ \\ wildan_saragih@ymail.com ${ }^{1}$, rinahayati.maulidiah@yahoo.com²
}

\begin{abstract}
ABSTRAK
Penelitian ini bertujuan untuk melihat keefektifan pemanfaatan media pembelajaran berbasis etnomatematika dengan permainan ular tangga pada mata kuliah media pembelajaran untuk meningkatkan prestasi akademik mahasiswa semester VI Program Studi Pendidikan Matematika FKIP UNA Tahun Akademik 2016/2017. Sampel penelitian ini dua kelas yaitu kelas VIA (Kelas eksperimen) dan kelas VIB ( kelas kontrol). Nilai rata-rata pretes kelas eksperimen $(64,82)$ dengan nilai tertingginya 82 dan nilai terendah 46, nilai pretes kelas kontrol $(61,48)$ dengan nilai tertinggi 78 dengan nilai terendah 42 . Dari uji homogenitas pretes tidak terdapat perbedaan varians atau kedua sampel homogen dimana $F_{\text {hitung }}<F_{\text {tabel }}$ (1,86). Dari uji normalitas data pretes diperoleh $L_{0}$ kelas eksperimen $(0,1274)$ dan $L_{0}$ kelas kontrol $(0,117)$. Untuk data postes diperoleh $L_{0}$ kelas eksperimen $(0,1587)$ dan $L_{0}$ kelas kontrol $(0,1082)$. Nilai $L_{0}$ tersebut lebih kecil dari $L_{\text {tabel }}(0,161)$ sehingga di simpulkan data berdistribusi normal. Nilai rata-rata postes kelas eksperimen $(87,9)$ dengan nilai tertinggi 90 dan nilai terendah 63, sedangkan untuk kelas kontrol nilai rata-rata postes $(80,6)$ dengan nilai tertinggi 90 dan nilai terendah 54. Dari uji t diperoleh $t$ hitung $=2,11>t_{\text {tabel }}=2,01$ yang artinya $H_{a}$ diterima yaitu rata-rata prestasi akademik mahasiswa yang di ajar dengan memanfaatkan media pembelajaran berbasis etnomatematika dengan permainan ular tangga lebih baik dari rata-rata data mahasiswa yang diajar tanpa memanfaatkan media pembelajaran berbasis etnomatematika permainan ular tangga.
\end{abstract}

\section{Kata kunci : Keefektifan, Pembelajaran Berbasis Etnomatematika, Media Permainan Ular Tangga, Prestasi akademik Mahasiswa}

\section{PENDAHULUAN}

Pendidikan merupakan kunci untuk peradaban dan kesejahteraan yang di cita- citakan. Melalui pendidikan akan terjadi proses pendewasaan diri sehingga dalam proses pengambilan keputusan terhadap suatu masalah yang di hadapi selalu disertai dengan rasa tanggung jawab yang besar. Oleh sebab itu proses belajar di kampus merupakan kegiatan yang sangat penting dalam peningkatan kualitas pendidikan. Karena dengan adanya pendidikan dapat melahirkan generasi-generasi manusia yang berilmu,baik itu pendidikan formal maupun nonformal.

Ilmu pendidikan adalah salah satu ilmu yang berperan penting dalam perkembangan ilmu pengetahuan dan teknologi. Pendidikan merupakan alat dan sarana pendidikan yang diperlukan untuk mengembangkan cabang ilmu yang lain. Ilmu pengetahuan lainnya tidak akan bisa berjalan dengan sempurna tanpa adanya dukungan pendidikan yang dapat mengembangkan daya nalar dan daya berpikir yang tinggi.

Dalam pembelajaran mata kuliah media di kampus, mata kuliah ini di pandang mahasiswa sebagai mata kuliah yang sangat sulit dipelajari, hal ini di tunjukkan dengan banyaknya mahasiswa yang mengalami kesulitan mendesain media pendidikan. Kesulitan mahasiswa mendesain media pembelajaran bisa disebabkan oleh berbagai hal seperti penyampaian materi ajar yang kurang menarik dari dosen, keterbatasan waktu, pengelolaan kelas yang kurang terprogram dan kondisi kelas yang kurang memungkinkan. Sehingga 
akan mempengaruhi konsentrasi mahasiswa untuk menerima pelajaran.Selain itu, dilihat dari strategi pembelajaran yang diterapkan masih mengikuti metode - metode yang pada umumnya monoton.

Strategi belajar mengajar yang digunakan dosen cenderung masih menggunakan metode yang monoton. Dosen hanya memberi materi, contoh media, dan kemudian tugas. Keadaan ini membuat mahasiswa menjadi bosan dan tidak ada keinginan untuk mengikuti pembelajaran media. Selain itu peran dosen terlihat dominan karena yang berperan lebih aktif adalah dosen.Pemahaman yang diperoleh mahasiswa hanya sebatas apa yang di sampaikan oleh dosen.

Fungsi media dalam kegiatan tersebut sebagai penyaji stimulus informasi,sikap,juga untuk meningkatkan keberhasilan dalam menerima informasi. Media juga berfungsi untuk mengatur langkah langkah kemajuan serta untuk memberikan umpan balik pada proses belajar mengajar. Dengan menggunakan media pembelajaran tidak terkesan membosankan bagi mahasiswa, karena mahasiswa tidak hanya mendengarkan ceramah dari dosen tetapi dengan menggunakan media pembelajaran mahasiswa akan lebih tertarik dengan pelajaran yang disampaikan dan mahasiswa akan terdorong motivasi belajarnya serta memperjelas dan mempermudah konsep yang abstrak dan mempertinggi daya serap atau retensi belajar. Oleh karena itu, diharapkan dengan penggunaan media dapat membantu proses belajar mengajar yang pada akhirnya dapat berpengaruh positif terhadap prestasi akademik mahasiswa di kampus.

Mutu pembelajaran merupakan sesuatu yang dinamis, relevan dengan kebutuhan masyarakat dan pengguna lulusan, berbudaya akademik dalam penyelenggaraan pembelajaran, adanya komitmen pembelajaran dari para dosen dan mahasiswa untuk meningkatkan mutu pembelajaran dan pengelolaan pembelajaran yang efektif dan efesien, memperhatikan keberlanjutan program, efisiensi serta tingginya akses terhadap perkembangan informasi. Pembelajaran yang bermutu akan menghasilkan lulusan yang berkualitas pula, sedangkan untuk menghasilkan pembelajaran yang bermutu dibutuhkan lulusan yang kreatif dalam mengupayakan proses pembelajaran yang profesional. Program pengembangan media pembelajaran bagi mahasiswa merupakan salah satu cara yang dapat digunakan mahasiswa sebagai calon guru untuk dapat mengatasi jenuhnya pembelajaran didalam kelas,sehingga diharapkan mahasiwa mempunyai kompetensi dalam mengembangkan media yang sesuai dengan perubahan dan tantangan zaman sekaligus untuk menepis anggapan bahwa rendahnya prestasi akademik mahasiswa di sekolah dikarenakan rendahnya kompetensi dan kreativitas dosen dalam menggunakan media.

Menurut Arsyad (2007:3), kata media berasal dari Bahasa Latin,yakni medius yang secara harfiahnya berarti“tengah"pengantar atau perantara.Dalam hal ini dosen,buku teks, dan lingkungan sekolah merupakan media. Secara lebih khusus, pengertian media dalam proses belajar mengajar cenderung diartikan sebagai alat - alat grafis, photografis, atau elektronis untuk menangkap, memproses, dan menyusun kembali informasi visual atau verbal. Berdasarkan definisi tersebut diatas, dapat dikatakan bahwa media pembelajaran merupakan sarana perantara dalam proses pembelajaran. Pada hakekatnya, proses belajar mengajar adalah proses komunikasi, penyampaian pesan dari pengantar ke penerima. Dalam penafsiran tersebut, ada kalanya mahasiswa berhasil dan adakalanya tidak berhasil atau gagal. Kegagalan terjadi jika mahasiswa tidak mampu memahami apa yang didengar, dibaca, dilihat, ataupun diamati. Kegagalan itu disebabkan oleh gangguan yang menjadi penghambat komunikasi. Berdasarkan hal tersebut, Daryanto (2011:4-5) media harus bermanfaat sebagai berikut : (1) Memperjelas pesan agar tidak terlalu verbalistis. (2) Mengatasi keterbatasan ruang, waktu, tenaga, dan daya indera. (3) Menimbulkan gairah belajar, berinteraksi secara langsung antara mahasiswa dan sumber belajar. (4) Memungkinkan anak belajar mandiri sesuai dengan bakat dan kemampuan visual, auditori, dan kinestetikanya. (5) Memberikan rangsangan yang sama, mempersamakan pengalaman, dan menimbulkan persepsi yang sama. (6) Proses pembelajaran mengandung lima komponen komunikasi, yaitu guru (komunikator), bahan pembelajaran, media pembelajaran, mahasiswa (komunikan), dan tujuan pembelajaran. Jadi, media pembelajaran adalah segala sesuatu yang dapat digunakan untuk menyalurkan pesan (bahan pembelajaran) sehingga dapat merangsang perhatian, minat, fikiran, dan perasaan mahasiswa dalam kegiatan belajar untuk mencapai tujuan pembelajaran.

Menurut Gagne (dalam Daryanto 2011:16) media diklasifikasikan menjadi tujuh kelompok, yaitu benda yang didemonstrasikan, komunikasi lisan, media cetak, gambar diam, gambar bergerak, film bersuara, dan mesin belajar. Ketujuh kelompok media pembelajaran tersebut dikaitkan dengan kemampuannya memenuhi fungsi menurut hirarki belajar yang dikembangkan, yaitu pelontar stimulus belajar, penarik minat belajar, contoh perilaku belajar, memberi kondisi eksternal, menuntun cara berfikir, memasukkan alih ilmu, menilai prestasi, dan pemberi umpan balik. Dalam proses pembelajaran, media memiliki fungsi sebagai pembawa informasi dari sumber (dosen) menuju penerima (mahasiswa). Adapun 
metode adalah untuk membantu mahasiswa dalam menerima dan mengolah informasi guna mencapai tujuan pembelajaran. Menurut Arsyad (2007 : 4) menyatakan bahwa media merupakan alat saluran komunikasi.Media tersebut dapat dipertimbangkan sebagai media pembelajaran jika membawa pesanpesan dalam rangka mencapai tujuan pembelajaran. Pada awal sejarah pembelajaran, media hanya sebagai alat bantu yang digunakan oleh dosen untuk menyampaikan pelajaran. Berbeda dengan saat ini, kehadiran media pembelajaran juga dapat memberikan stimulus maupun pengembangan aspek intelektual maupun emosional mahasiswa melalui media pembelajaran berbasis etnomatematika.

Etnomatematika adalah pendekatan yang digunakan untuk pembelajaran matematika menggunakan media budaya yang ada di sekitar mahasiswa. Etnomatematika memiliki arti yang luas bukan sekedar etno (etnis) atau suku. Tetapi juga berhubungan dengan kebiasaan yang ada di masyarakat atau lingkungan tempat tinggal mahasiswa. Dengan etnomatematika pembelajaran matematika dapat disesuaikan dengan kebutuhan. Meskipun pembelajaran etnomatematika berbasis budaya (masyarakat sekitar) bukan berarti kuno tetapi pembelajaran yang inovatif dan memiliki perspektif global. Pembelajaran dengan etnomatematika lebih cocok digunakan daripada pembelajaran matematika tradisional karena merupakan pembelajaran matematika realistik (nyata, ada di kehidupan sehari-hari). Dalam pembelajaran etnomatematika dosen dapat menggunakan budaya sebagai media pembelajaran matematika. Budaya tersebut dapat berupa artefak, karya maupun tingkah laku masyarakat sekitar seperti permainan tradisional. Dosen dapat mengkolaborasikan budaya yang ada dengan materi matematika yang ada di sekolah, misalnya pada pembelajaran trigonometri dosen dapat menggunakan ilustrasi dengan desain permainan ular tangga.

Dengan etnomatematika mahasiswa akan tertarik belajar matematika, pembelajaran menyenangkan, memahami makna matematika dan tujuan pembelajaran matematika dapat tercapai. Namun perkembangan matematika di Indonesia belum begitu baik. Sedikit dosen yang menggunakan pendekatan ini. Banyak dosen masih menggunakan metode pembelajaran konvensional. Banyak dosen yang beranggap bahwa menggunakan etnomatematika rumit karena butuh inovasi dan dosen harus bekerja lebih. Selain itu banyak dosen ataupun sekolah yang beranggapan bahwa menggunakan etnomatematika kurang efektif dan membuang waktu untuk latihan soal. Saat ini banyak dosen atau kepala sekolah yang berusaha membangun citra baik sekolah dengan mengukir nilai yang tinggi di Ujian Nasional yaitu dengan banyak melakukan drill soal setara ujian nasional yang sangat teoritis dan tidak mengandung masalah matematika yang ada di kehidupan sehari-hari. Dengan cara seperti itu mahasiswa memang jadi pandai menerapkan rumus dan melakukan kalkulasi untuk menemukan solusi yang ada di soal. Namun ketika dihadapkan pada soal cerita dengan masalah matematika realistik yang ada di kehidupan sehari-hari mahasiswa banyak yang bingung dan tidak mampu menyelesaikannya.

Di rasa bahwa banyak dosen yang menganggap etnomatematika kurang penting dan kurang efektif. Padahal etnomatematika membuat mahasiswa sadar bahwa matematika dekat dengan kehidupan mereka dan membuat motivasi belajarnya tinggi. Untuk itu diperlukan pemahaman kepada dosen-dosen ataupun calon guru terutama yang masih muda dan penuh inovasi agar menyadari pentingnya etnomatematika dan dapat menerapkannya pada pembelajarannya di sekolah.

\section{OBJEKTIF PENELITIAN}

Objektif penelitian secara khusus adalah untuk mendapatkan gambaran tentang keefektifan pemanfaatan media pembelajaran berbasis etnomatematika dengan permainan ular tangga pada mata kuliah media pembelajaran untuk meningkatkan prestasi akademik mahasiswa semester VI Program Studi Pendidikan Matematika FKIP UNA Tahun Akademik 2016/2017.

\section{METODE PENELITIAN}

Jenis penelitian ini adalah penelitian quasi eksperimen yaitu mengetahui ada tidaknya perbedaan akibat pengaruh dari sesuatu yang dikenakan pada mahasiswa sebagai subjek penelitian. Pengaruh yang dimaksud adalah peningkatan prestasi akademik mahasiswa dengan Media pembelajaran berbasis etnomatematika permainan ular tangga yang telah ditentukan dapat dilihat dari hasil jawaban mahasiswa pada tes prestasi akademik. Prestasi akademik mahasiswa yang dimaksud adalah skor dan nilai yang diperoleh mahasiswa setelah diberikan tes pada akhir eksperimen. 
Untuk memperoleh data prestasi akademik maka peneliti menggunakan teknik pengumpulan data berupa tes akhir yang dilaksanakan diakhir eksperimen yang diambil dari soal-soal Ujian Nasional materi turunan trigonometri. Bentuk tes adalah pilihan ganda. Apabila benar mendapatkan skor 1 dan apabila salah mendapatkan skor 0 .

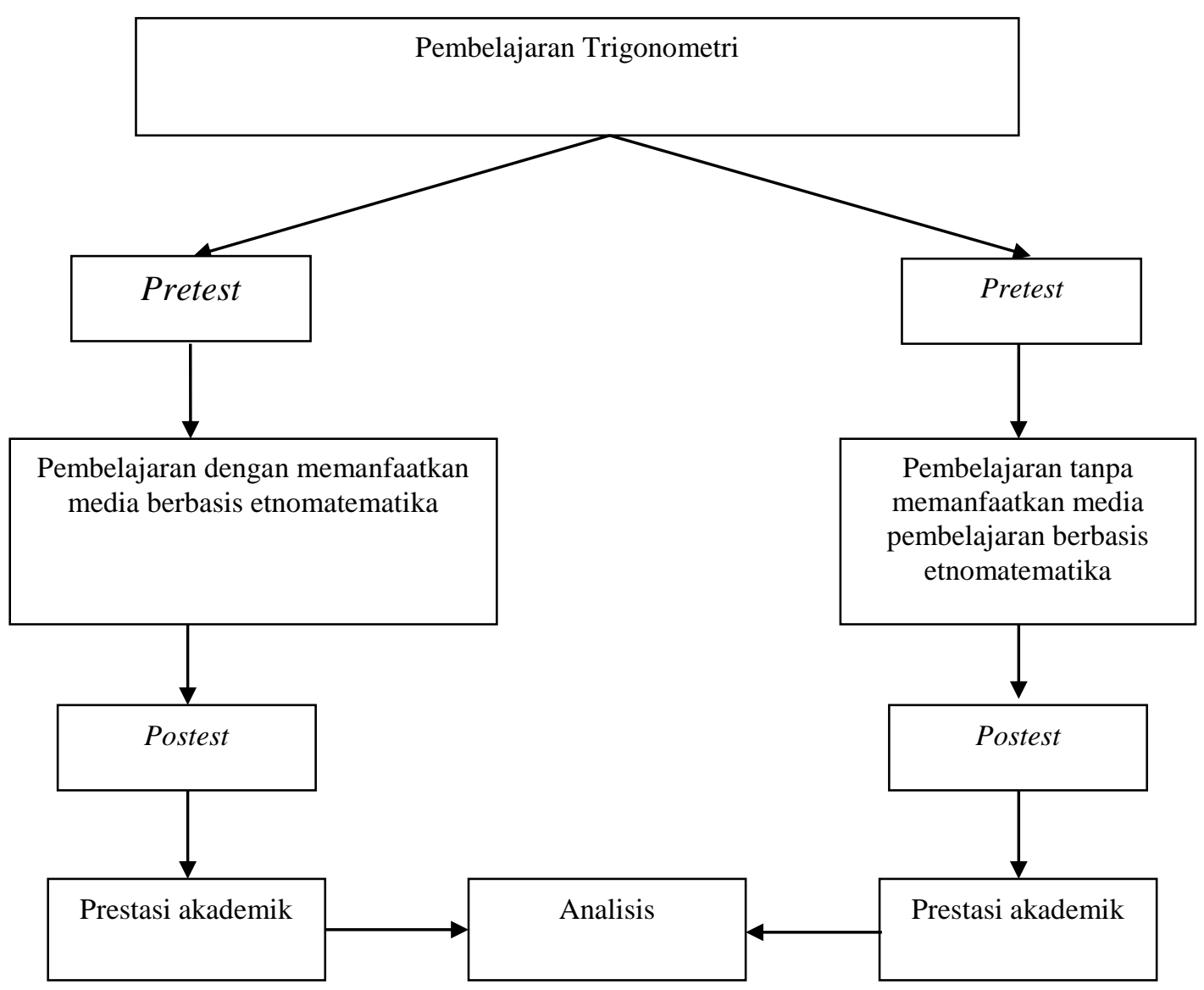

\section{Gambar 3.1 Prosedur Penelitian}

Untuk memperoleh data prestasi akademik maka peneliti menggunakan teknik pengumpulan data berupa tes akhir yang dilaksanakan diakhir eksperimen yang diambil dari soal-soal Ujian Nasional materi logika matematika. Bentuk tes adalah pilihan ganda. Apabila benar mendapatkan skor 1 dan apabila salah mendapatkan skor 0.

\section{HASIL DAN PEMBAHASAN}

Hasil penelitian pada kelompok eksperimen dan kelompok kontrol berasal dari kondisi awal yang sama, yaitu setelah diadakan uji normalitas dan homogenitas yang menunjukkan bahwa sampel berdistribusi normal dan tidak ada perbedaan varians.Kemudian dilakukan uji kesamaan dua rata-rata yang menunjukan bahwa sampel mempunyai kesepadanan. Pada kelompok eksperimen diberi perlakuan model pembelajaran dengan memanfaatkan media pembelajaran berbasis etnomatematika yaitu permainan ular tangga sedangkan pada kelompok kontrol diberi perlakuan model pembelajaran tanapa memanfaatkan media pembelajaran berbasis etnomatematika yaitu permainan ular tangga. Proses pembelajaran pada kelompok eksperimen diawali dengan pembagian materi yang sesuai kompetensi dasar serta tujuan pembelajaran. 
Setelah dilakukan perlakuan keduanya diadakan tes hasil belajar.Tes prestasi akademik telah diujicobakan sebelumnya dikelas uji coba dan dilakukan uji validitas,uji reliabilitas, daya beda dan taraf kesukaran item soal.Hasil yang diperoleh bahwa tes tersebut reliabel dan item soal memenuhi validitas item. Berdasarkan data yang diperoleh dapat diketahui bahwa nilai rata-rata prestasi akademik matematika mahasiswa yang diajarkan dengan menggunakan Model Pembelajaran dengan memanfaatkan media pembelajaran berbasis etnomatematika yaitu permainan ular tangga pada materi turunan trigonometri $(89,18)$ lebih tinggi dari nilai rata-rata prestasi akademik matematika mahasiswa yang diajarkan dengan menggunakan model pembelajaran tanpa memanfaatkan media pembelajaran berbasis etnomatematika yaitu permainan ular tangga (78,37). Hasil penelitian menunjukkan bahwa terdapat Pengaruh Media pembelajaran berbasis etnomatematika permainan ular tangga pada materi Turunan trigonometri terhadap prestasi akademik mahasiswa program studi pendidikan FKIP UNA. Hal ini dimungkinkan dipengaruhi oleh: (1) Dengan pengajuan masalah dari mahasiswa sendiri akan mendidik mahasiswa berfikir kritis. (2) Dengan Membuat kelompok Mahasiswa aktif dalam pembelajaran. (3) Perbedaan pendapat antara mahasiswa dapat diketahui sehingga mudah diarahkan pada diskusi yang sehat. (4) Meneyelesaikan masalah yang mahasiswa buat sendiri akan mengajarkan mahasiswa menaganlisis suatu masalah. (5) Mempresentasekan hasil diskusi Mendidik mahasiswa lebih percaya diri.

\section{KESIMPULAN}

Berdasarkan hasil penelitian ditemukan bahwa nilai rata-rata pretes kelas eksperimen $(64,82)$ dengan nilai tertingginya 82 dan nilai terendah 46, nilai pretes kelas kontrol $(61,48)$ dengan nilai tertinggi 78 dengan nilai terendah 42. Dari uji homogenitas pretes tidak terdapat perbedaan varians atau kedua sampel homogen dimana $\mathrm{F}_{\text {hitung }}<\mathrm{F}_{\text {tabel }}(1,86)$. Dari uji normalitas data pretes diperoleh $\mathrm{L}_{0}$ kelas eksperimen $(0,1274)$ dan $\mathrm{L}_{0}$ kelas kontrol $(0,117)$. Untuk data postes diperoleh $\mathrm{L}_{0}$ kelas eksperimen $(0,1587)$ dan $\mathrm{L}_{0}$ kelas kontrol $(0,1082)$. Nilai $\mathrm{L}_{0}$ tersebut lebih kecil dari $\mathrm{L}_{\text {tabel }}(0,161)$ sehingga di simpulkan data berdistribusi normal. Nilai rata-rata postes kelas eksperimen $(87,9)$ dengan nilai tertinggi 90 dan nilai terendah 63, sedangkan untuk kelas kontrol nilai rata-rata postes $(80,6)$ dengan nilai tertinggi 90 dan nilai terendah 54. Dari uji $t$ diperoleh $\mathrm{t}_{\text {hitung }}=2,11>\mathrm{t}_{\text {tabel }}=2,01$ yang artinya $\mathrm{H}_{\mathrm{a}}$. diterima yaitu rata-rata prestasi akademik mahasiswa yang di ajar dengan memanfaatkan media pembelajaran berbasis etnomatematika dengan permainan ular tangga lebih baik dari rata-rata data mahasiswa yang diajar tanpa memanfaatkan media pembelajaran berbasis etnomatematika permainan ular tangga. Dari hasil analisis data yang dilakukan dalam penelitian ini dapat diambil kesimpulan sebagai berikut : (1) Dengan model pembelajaran dan memanfaatkan Media Pembelajaran Ular Tangga, mahasiswa lebih memahami dalam pembelajaran Turunan trigonometri, dikarenakan mahasiswa lebih aktif dalam proses pembelajaran dan dapat menumbuhkan pemikiran yang kritis menunjukkan rata-rata yang lebih tinggi di kelas eksperimen sedangkan rata-rata di kelas kontrol lebih rendah.

\section{SARAN}

Adapun saran yang dapat diambil dari hasil penelitian yang diperoleh, iaitu: (1) Kepada kepala sekolah disarankan agar menerapkan perpaduan model dan media pembelajaran yang lebih efektif dan sesuai dengan materi yang diajarkan di sekolah agar prestasi akademik mahasiswa dapat lebih baik. (2) Kepada peneliti yang berminat melakukan penelitian sejenis supaya melakukan persiapan dengan teliti dan cermat untuk mengalokasikan waktu yang digunakan dalam menerapkan pembelajaran yang menggunakan media pembelajaran berbasis etnomatematika yaitu permainan ular tangga pada materi Turunan trigonometri. (4) Kepada Mahasiswa memberi masukan untuk meningkatkan kreatifitas belajar nya, mengoptimumkan kemampuan berfikir positif dalam mengembangkan diri di tengah-tengah lingkungan dalam meraih keberhasilan belajar. 


\section{RUJUKAN}

Alfatih, H, 2012, Realistic Mathematic Education (RME) Atau Pembelajaran Matematika Realistik Indonesia (PMRI), Online.(http://cigoreku.blogspot.com/2012/10/realistic-mathematic education-rme-atau -html [ diakses tanggal 10 Desember 2015]

Arikunto. 2006. Dasar-Dasar Evaluasi Pendidikan. Jakarta: Bumi Aksara.

Arikunto. 2010. Prosedur Penelitian. Jakarta: PT. Asdi Mahasatya.

Arsyad.2007. Media Pembelajaran. Jakarta: PT. RajaGrafindo.

Daryanto. 2011. Media Pembelajaran. Bandung: PT. Sarana Tutorial Nurani Sejahtera.

Dimyati. 2006. Belajar dan Pembelajaran. Rieneka cipta. Jakarta.

Hammond, T. 2000, Ethnomathematics: Concept Defenition and Research Perspective. Thesis for Degree of master of Arts, Columbia University

Shoimi, 2014.68 Model Pembelajaran inovatif. Jakarta: Bumi Aksara.

Slameto. 2013. Belajar dan Faktor-Faktor Yang Mempengaruhi. Jakarta: Rineka Cipta.

Sudjana.2005. Metoda Statistika. Bandung: PT. Tarsito Bandung.

Sugiyono.2013.Metodologi Penelitian Pendidikan.Bandung:Alfabeta.

Sukmawarti. 2012. Evaluasi Proses dan Hasil Pembelajaran Matematika. Medan: Prodi Pendidikan

Matematika Fakultas Kedosenan dan Ilmu Pendidikan.

Syah. 2010 psikologi pendidikan(edisi revisi). Bandung : Rosda 